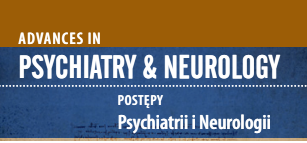

Correspondence to/

Adres do korespondencji:

Agnieszka Kruczek

Instytut Psychologii

Uniwersytet Kazimierza Wielkiego

w Bydgoszczy

ul. Leopolda Staffa 1

85-867 Bydgoszcz, Polska

e-mail: agnesview@gmail.com

Submitted/Otrzymano: 11.03 .2018

Accepted/Przyjęto do druku: 13.08.2018

\section{HUMOUR, STRESS AND COPING IN ADULTS}

\section{HUMOR, STRES I RADZENIE SOBIE Z NIM U LUDZI DOROSŁYCH}

\author{
Agnieszka Kruczek, Małgorzała Anna Basińska
}

Department of Psychopathology and Clinical Diagnosis, Institute of Psychology, Kazimierz Wielki University, Bydgoszcz, Poland

Zakład Psychopatologii i Diagnozy Klinicznej, Instytut Psychologii, Uniwersytet Kazimierza Wielkiego, Bydgoszcz, Polska

\begin{abstract}
Purpose: The study focused on the functional character of humour, especially on its role in coping with stress. The purpose of the study was to assess the differences in humour coping by gender and age; to recognize the nature of the relationship between humour coping and coping styles, coping strategies and sense of stress; to recognize the mediating role of coping humour in relationship between coping with stress styles and sense of stress.

Method: A total of 199 persons (113 females and 86 males) were included in the study, aged from 20 to 60 years. Mean age in the study group was $37.76(\mathrm{SD}=12.04)$. The following methods was used in the study: CISS, Mini-COPE, Stress Sense Questionnaire (KPS), Coping Humour Scale (CHS) and socio-demographic questionnaire.

Results: Data analysis show that women were less likely than men to cope with stress using humour. Younger people less likely than older to cope with stress using humour. There are positive correlations between humour coping with stress and coping styles and strategy - positive reinterpretation and growth and a sense of humour.

Conclusions: Coping with stress using humour depends on gender and age and is positively correlated with adaptive coping stress style and coping strategies and negatively with sense of stress.
\end{abstract}

Key words: stress, humour coping, coping styles, adults, coping strategies.

\title{
Streszczenie
}

Cel: W badaniu skoncentrowano się na funkcjonalnym charakterze humoru, a w szczególności na jego roli w radzeniu sobie ze stresem. Celem badań uczyniono ocenę zróżnicowań w zakresie radzenia sobie przez humor ze względu na płeć i wiek; poznanie charakteru związków pomiędzy radzeniem sobie przez humor a stylami i strategiami radzenia sobie ze stresem oraz poczuciem stresu; określenie mediacyjnej roli radzenia sobie przez humor dla związku pomiędzy stylami radzenia sobie ze stresem a poczuciem stresu. Metoda: Do badań zakwalifikowano łącznie 199 osób (113 kobiet i 86 mężczyzn) w wieku od 20 do 60 lat. Średnia wieku w grupie badanej wyniosła $\mathrm{M}=37,76$ ( $\mathrm{SD}=12,04)$. W badaniach zastosowano następujące metody: Kwestionariusz Radzenia Sobie w Sytuacjach Stresowych (CISS), Inwentarz do Pomiaru Radzenia Sobie ze Stresem Mini-COPE, Kwestionariusz Poczucia Stresu (KPS), Skalę Radzenia Sobie przez Humor (CHS) oraz ankietę własną.

Wyniki: Analizy danych pokazują, że kobiety w mniejszym stopniu radzą sobie ze stresem poprzez humor niż mężczyźni. Młodsi badani radzą sobie przez humor rzadziej niż osoby starsze. Występują pozytywne związki pomiędzy radzeniem sobie przez humor a stylem skoncentrowanym na zadaniu oraz strategią pozytywnego przewartościowania. Osoby, które preferują styl radzenia sobie ze stresem skoncentrowany na zadaniu, przez szersze zastosowanie humoru odczuwają mniejsze poczucie stresu.

Wnioski: Radzenie sobie przez humor zależne jest od płci i wieku oraz jest pozytywnie związane z aktywnymi stylami i strategiami radzenia sobie ze stresem oraz mediuje związek pomiędzy stylem skoncentrowanym na zadaniu a poczuciem stresu.

Słowa kluczowe: stres, radzenie sobie przez humor, style radzenia sobie, strategie radzenia sobie, dorośli. 


\section{INTRODUCTION}

The research on humour is part of the research on positive psychology which was borne at the end of the $20^{\text {th }}$ century [1]. In the source literature, humour was treated in a multidimensional way as a feature of personality, temperament [2], a tendency to laugh and joke at other people [3], and the ability to do so [4].

With the development of positive psychology [1], the focus started to be on the functional character of humour and in particular on its role in shaping the psychological well-being of the individual. According to the cognitive-transactional theory of stress [5], humour can be treated as a subjective resource for an individual to cope with difficult situations [cf. 3,6] Research in this field allows us to recognise humour as an extremely important mechanism regulating the psychophysical balance of the individual $[1,7,8]$.

Humour coping is seen as a property of an individual expressed in the use of humour to deal with situations that are described as stressful or demanding. It also includes efforts to maintain a humorous perspective in the face of adversity [3]. Humour coping should be conceptually distinguished from other individual traits (which in literature are associated with mental resilience), such as optimism (i.e. a tendency to expect favourable life solutions) or positive affectiveness (i.e. a tendency to feel positive emotions, such as enthusiasm or energy), because humour coping focuses primarily on the use of a specific behavioural strategy rather than on changing the individual's $\operatorname{mood}[9]$.

The humour coping theory developed by Rod A. Martin [11] is shaped by Richard Lazarus' and Susan Folkman's cognitive and transactional theory of stress [5], Sigmund Freud's concept [12], and the theory of contradiction of humour stimuli presented by Jerry M. Suls [13].

In the context of cognitive-transactional stress theory, humour can be treated as a form of cognitive assessment, which, in this case, consists of perceiving potentially stressful situations in a less threatening and funnier way $[5,14]$. The ability to apply humour in response to stress and failure can be significant in effective coping $[12,15,16]$.

Referring to Sigmund Freud's concept, it is not limited to the description of unresolved tensions caused by stressful situations. He emphasises the psychic energy that accumulates in the individual every day, even in the face of little stressful situations. These amounts of unused energy can be released by the humour [12]. According to Freud [12], humour can be sorted into three categories: joke, comic and mimetic. Each of these three categories involves a different mechanism through

\section{WPROWADZENIE}

Problematyka badawcza z zakresu humoru wpisuje się w nurt badań psychologii pozytywnej, która zrodziła się pod koniec XX wieku [1]. W literaturze przedmiotu humor był traktowany wielowymiarowo, jako: cecha osobowości, temperamentu [2], tendencja do śmiania się i żartowania z innych ludzi [3], zdolność [4].

Wraz z rozwojem psychologii pozytywnej [1] zaczęto koncentrować się na funkcjonalnym charakterze humoru, a w szczególności na jego roli w kształtowaniu dobrostanu psychofizycznego jednostki. Zgodnie z poznawczo-transakcyjną teorią stresu [5] humor można traktować jako zasób podmiotowy jednostki, pozwalający jej radzić sobie z sytuacjami trudnymi [por. 3, 6]. Badania w tym nurcie pozwalają uznać humor za niezwykle istotny mechanizm regulujący psychofizyczną równowagę jednostki $[1,7,8]$.

Radzenie sobie przez humor jest ujmowane w kategoriach właściwości indywidualnej jednostki, wyrażającej się w wykorzystywaniu humoru w celu poradzenia sobie z sytuacjami określanymi jako stresujące czy wymagające. Obejmuje wysiłki mające na celu utrzymanie humorystycznej perspektywy w obliczu przeciwności [3]. Radzenie sobie przez humor należy odróżnić pod względem koncepcyjnym od innych cech jednostki (które w literaturze naukowej wiązane są z odpornością psychiczną), takich jak optymizm (czyli skłonność do oczekiwania korzystnych rozwiązań życiowych) lub pozytywna afektywność (czyli skłonność do odczuwania pozytywnych emocji, takich jak entuzjazm lub energia), ponieważ radzenie sobie przez humor koncentruje się zasadniczo na wykorzystywaniu konkretnej strategii behawioralnej, a nie na zmianie nastroju jednostki [9].

Teoria radzenia sobie przez humor, którą rozwija Rod A. Martin [11], czerpie z poznawczo-transakcyjnej teorii stresu Richarda Lazarusa i Susan Folkman [5], koncepcji Zygmunta Freuda [12], teorii wyższości oraz teorii sprzeczności bodźców humoru prezentowanej przez Jerry'ego M. Sulsa [13].

W kontekście poznawczo-transakcyjnej teorii stresu humor może być traktowany jako forma oceny poznawczej, która w tym przypadku polega na postrzeganiu potencjalnie stresujących sytuacji w mniej zagrażający, a bardziej zabawny sposób $[5,14]$. Zdolność zastosowania humoru w odpowiedzi na stres i niepowodzenie może być znacząca w efektywnym radzeniu sobie $[12,15,16]$.

Odnosząc się do teorii Z. Freuda [12], nie ogranicza się ona jedynie do opisu nierozładowanych napięć, spowodowanych stresującymi sytuacjami. Kładzie nacisk na energię psychiczną, która gromadzi się w jednostce każdego dnia, nawet w obliczu mało stresujących sytuacji. Te pokłady niewykorzystanej energii mogą być uwalniane poprzez humor [12]. Według Freuda [12] humor jest jedną z trzech kategorii śmiechu obok dowcipu i kawału. Każda $\mathrm{z}$ tych trzech kategorii angażuje inny mechanizm, 
which psychic energy is accumulated and then dispersed through laughter.

According to the representatives of the psychoanalytical trend, if the mind perceives disturbing stimuli, an intruder alarm is automatically activated. It is activated with new, unexpected or contrary to expected stimuli. It results from the significance of ambiguities, inconsistencies and anomalies for the survival of humanity - each of which could mean a threat [17]. When the safety mechanism remains active, the focus is increased. A similar reaction is caused by the incoherencies contained in the humorous stimulus. The organism mobilises the forces to react to a possible danger; however, when, after solving the inconsistency, it turns out that the danger did not occur, the alarm is switched off. Furthermore, the human body has significant amounts of energy reserved for the possible activation of the 'fight or flight' mechanism, which excess can be released through laughter [17].

In the theory of superiority, humour is defined as a form of funny aggression that plays an extremely important role in the process of coping. By laughing at other people or situations that are perceived as dangerous or difficult, an individual is able to break away from these negative aspects while experiencing positive emotions and well-being [10].

Martin [11] also referred to The Incongruity Theory presented by Suls [13], according to which humour consists of associating two divergent ideas, concepts or situations in a surprising, unexpected way. This shift in the perspective of humour has been seen by many authors as essential for its effectiveness in reducing the negative effects of stress. As a result, humour, thanks to its ability to relieve tension, makes it funny for what is in fact terrifying - a gloomy reality that turns into something worthy of ridicule and thus easier to bear.

Numerous research results confirm the existence of positive relationships between the use of humour and coping with stress $[10,11,14,20,21]$.

In light of the research by Kerri M. Lehman et al. [20], those who used humour more often to reformulate potentially stressful situations, showed a lower intensity of psychophysiological response to stress stimuli, which was measured, among other things, by observing their behaviour.

The results of the study by Kuiper, Martin, and Olinger [14] confirmed that those who used humour more often in coping with stressful situations perceived it more positively, namely as a challenge. In other studies, Kuiper et al. [21] proved that people who used humour more extensively in coping with stress had a greater ability to distance themselves from problems and look at a difficult situation from multiple perspectives. Furthermore, they poprzez który energia psychiczna jest kumulowana, a następnie rozpraszana za pomocą śmiechu.

Według przedstawicieli nurtu psychoanalitycznego, jeżeli umysł dostrzega niepokojące go bodźce, automatycznie włącza się mechanizm alarmowy (intruder alarm). Jest on aktywowany przy nowych, niespodziewanych lub sprzecznych z oczekiwaniami bodźcach. Wynika on ze znaczenia, jakie dla przetrwania ludzkości miały wieloznaczności, niezgodności i anomalie - każda z nich mogła oznaczać zagrożenie [17]. Kiedy mechanizm chroniący pozostaje aktywny, dochodzi do zwiększenia koncentracji uwagi. Podobną reakcję powoduje niespójność zawarta w bodźcu humorystycznym. Organizm mobilizuje siły do reakcji na ewentualne niebezpieczeństwo, kiedy jednak po rozwiązaniu niespójności okazuje się, że zagrożenie nie wystąpiło, alarm zostaje wyłączony. Ponadto organizm ludzki wyposażony jest w znaczne pokłady energii zarezerwowanej na ewentualne uruchomienie mechanizmu „walcz lub uciekaj”, której nadmiar może zostać uwolniony w śmiechu [17].

Na gruncie teorii wyższości humor jest definiowany jako forma zabawnej agresji, która odgrywa niezwykle istotną rolę $\mathrm{w}$ procesie radzenia sobie. Poprzez naśmiewanie się z innych ludzi czy sytuacji, które są spostrzegane w kategoriach zagrażających lub sprawiających trudność, jednostka jest w stanie oderwać się od tych negatywnych aspektów, doświadczając jednocześnie pozytywnych emocji i dobrostanu [10].

Martin [11] nawiązywał również do teorii sprzeczności bodźców humoru prezentowanej przez Sulsa [13], według którego humor polega na skojarzeniu dwóch rozbieżnych pomysłów, koncepcji lub sytuacji w zaskakujący, nieoczekiwany sposób. To przesunięcie w perspektywie towarzyszącej humorowi było postrzegane przez wielu autorów jako zasadnicze dla jego efektywności w zmniejszaniu negatywnych skutków stresu. W konsekwencji humor dzięki swojej zdolności rozładowywania napięcia, pozwala uczynić zabawnym to, co w rzeczywistości jest przerażające - ponurą rzeczywistość zamienia w coś godnego kpiny, a przez to łatwiejszego do zniesienia.

Liczne wyniki badań potwierdzają występowanie pozytywnych związków pomiędzy wykorzystaniem humoru a radzeniem sobie ze stresem $[10,11,14,20,21]$.

W świetle wyników badań Kerri M. Lehman i wsp. [20] osoby częściej wykorzystujące humor do przeformułowania potencjalnie stresującej sytuacji, prezentowały mniejsze natężenie psychofizjologicznej odpowiedzi na bodźce stresogenne, które mierzone było m.in. poprzez obserwację ich zachowania.

Wyniki badania Kuipera, Martina i Olingera [14] potwierdziły, że osoby, które częściej wykorzystywały humor $\mathrm{w}$ radzeniu sobie $\mathrm{z}$ sytuacjami stresującymi, postrzegały je w sposób bardziej pozytywny, a mianowicie jako wyzwanie. W innych badaniach Kuiper i wsp. [21] udowodnili, że osoby, które w szerszym zakresie wykorzystywały humor w radzeniu sobie ze stresem, posiadały większe zdolności dystansowania się od problemów i pa- 
made more use of the confrontational style of dealing with stressful situations.

In William W. Fry's research [22] coping with stress through humour was positively correlated with an emotion-focused coping orientation. As a result, individual regulated their own emotional reactions more effectively and took different philosophical approaches to the problem. People were more likely to seek instrumental and emotional social support. They showed a greater tendency to give vent to their own emotions, thus reducing mental tension.

More effective coping with stress through humour in the light of Millicent H. Abel's research [23] was associated with more frequent problem-solving planning, positive secondary assessment of the stressful situation and distancing oneself from it. People, who more often coped with stress through humour, managed their own emotions to a wider extent.

It should be mentioned that an individual who uses humour more frequently is able to contribute to a positive change in the social situation, also by providing social support. Therefore, people with a higher sense of humour are considered to have greater social competences. Such people may find it easier to establish friendships and networks of social support. Individuals with a greater sense of humour were able to solve their problems more efficiently, because due to the social support (expressed, among other things, in the provision of various guidelines) they perceived a multitude of solutions to the stressful situation $[3,10]$. As a result, they enjoyed better physical and mental health $[1,7,11,22]$.

To sum up, the results of research on humour coping to date show that people who use humour more frequently to cope with stress had a more realistic and flexible threatening cognitive assessment of a potentially stressful situation. They coped with stress using a variety of preventive and defensive strategies, and managed their emotions more effectively. They were characterised by higher adaptability. The fundamental importance of humour in dealing with extreme stress was emphasised by Viktor Frankl [for: 8], who in the context of experiences of people imprisoned in concentration camps during World War II described humour as a "different kind of weapon for the soul in the struggle for survival".

\section{PURPOSE}

The objective of the study was to identify gender and age differences in humour coping; to explore relations between humour coping and sense of stress, coping stress styles and strategies; and to explore the intermediary role of humour coping in the relationship between coping stress strategies and sense of stress. trzenia na sytuację trudną $\mathrm{z}$ wielu perspektyw. Ponadto częściej wykorzystywały konfrontacyjny styl radzenia sobie z sytuacjami stresującymi.

W badaniach Williama W. Frya [22] radzenie sobie ze stresem przez humor było pozytywie skorelowane z orientacją radzenia sobie skoncentrowaną na emocjach. W konsekwencji osoby efektywniej regulowały własne reakcje emocjonalne oraz podejmowały zróżnicowane podejścia filozoficzne do problemu. Osoby częściej poszukiwały instrumentalnego i emocjonalnego wsparcia społecznego. Prezentowały większą tendencję w zakresie dawania upustu własnym emocjom, dzięki czemu redukowały napięcie psychiczne.

Bardziej efektywne radzenie sobie ze stresem poprzez humor w świetle wyników badań Millicenta H. Abla [23] wiązało się z częstszym planowaniem rozwiązywania problemów, pozytywną wtórną oceną stresującej sytuacji oraz zdystansowaniem się od niej. Osoby, które częściej radziły sobie ze stresem przez humor w szerszym zakresie zarządzały własnymi emocjami.

Należy wspomnieć, że jednostka częściej posługująca się humorem jest w stanie przyczynić się do pozytywnej zmiany sytuacji społecznej, także poprzez udzielenie wsparcia społecznego. Stąd osoby z większym poczuciem humoru uznaje się za posiadające szersze kompetencje społeczne. Takim osobom może być łatwiej nawiązywać przyjaźnie i budować sieć wsparcia społecznego. Jednostki z większym poczuciem humoru były w stanie efektywniej rozwiązywać swoje problemy, gdyż dzięki wsparciu społecznemu (wyrażającemu się m.in. w dostarczaniu różnych wskazówek) dostrzegały wielość rozwiązań stresującej sytuacji $[3,10]$. W konsekwencji cieszyły się lepszym zdrowiem fizycznym i psychicznym $[1,7,11,22]$.

$\mathrm{Na}$ podstawie przedstawionych wyników dotychczasowych badań nad radzeniem sobie przez humor można stwierdzić, że osoby, które częściej wykorzystywały humor w celu poradzenia sobie ze stresem, posiadały bardziej realistyczną i elastyczną, a mniej zagrażającą ocenę poznawczą potencjalnie stresującej sytuacji. Radzily sobie ze stresem, korzystając ze zróżnicowanych strategii zaradczych i obronnych, efektywniej zarządzały emocjami. Charakteryzowały się większymi zdolnościami adaptacyjnymi. Fundamentalne znaczenie humoru $\mathrm{w}$ radzeniu sobie $\mathrm{z}$ ekstremalnym stresem podkreślał Viktor Frankl [za: 8], który w kontekście doświadczeń osób uwięzionych w obozach koncentracyjnych podczas drugiej wojny światowej określił humor jako „inny rodzaj broni dla duszy w walce o przetrwanie".

\section{CEL}

Celem badań było określenie zróżnicowań w zakresie radzenia sobie przez humor ze względu na płeć i wiek badanych, poznanie związków pomiędzy radzeniem sobie przez humor a poczuciem stresu, stylami i strategiami radzenia sobie ze stresem oraz poznanie pośredniczącej roli radzenia sobie przez humor dla związku pomiędzy stylami radzenia sobie ze stresem a poczuciem stresu. 
The following research hypotheses have been put forward in line with the objective:

H1: It was assumed that men would cope with stress through humour more often than women.

H2: It was assumed that young people would be less likely to cope with stress through humour than older people.

H3: It was assumed that there is a direct relationship between humour coping and coping stress styles. The task-oriented coping style would be positively related to humour coping. The emotion-oriented and avoidance-oriented coping styles would be negatively related to humour coping.

H4: It was assumed that there is a direct relationship between humour coping and coping stress strategies. Humour coping would be positively linked to adaptive coping strategies and negatively linked to maladaptive coping strategies.

H5: It was assumed that there is a direct relationship between humour coping and sense of stress. People who would use humour more often to cope with stress would feel less stressed.

H6: Humour coping would play an intermediate role in the relationship between coping stress styles and sense of stress.

\section{METHOD}

A total of 199 persons (113 females and 86 males) were included in the study, aged from 20 to 60 . The mean age in the study group was $\mathrm{M}=37.76(\mathrm{SD}=12.04)$. Females $(\mathrm{M}=38.85, \mathrm{SD}=11.55)$ and males $(\mathrm{M}=37.24$, $\mathrm{SD}=12.70)$ were of a similar age $(t=0.53, p=0.6)$. Respondents evaluated their social and living conditions on a scale from 0 to 10 at $\mathrm{M}=6.87(\mathrm{SD}=1.71)$. Whereas, they evaluated their health at the level of $\mathrm{M}=7.52(\mathrm{SD}=1.65)$.

\section{Research process}

The criteria for inclusion in the research group were as follows: reaching the age of 20 and performing professional work. The selection for the research group was purposeful, with the selection of people working professionally and various professions. The snowball method was used to collect data. The research was carried out with the use of questionnaire packages, the order of which was rotated in the package. Research participants received a package of questionnaires and, after completing the questionnaire, returned it within the set time limit. The research was carried out for one month (at the turn of February and March 2017).

\section{Research tools}

The following methods were used in the research: Coping Inventory for Stressful Situations (CISS), Brief
Adekwatnie do celu postawiono następujące hipotezy badawcze:

H1: Założono, że mężczyźni częściej będą radzili sobie ze stresem przez humor niż kobiety.

H2: Założono, że osoby młodsze rzadziej będą radziły sobie ze stresem przez humor niż osoby starsze.

H3: Założono występowanie bezpośredniego związku pomiędzy radzeniem sobie przez humor a stylami radzenia sobie ze stresem. Styl radzenia sobie ze stresem zadaniowy będzie pozytywnie związany z radzeniem sobie przez humor. Styl emocjonalny i unikowy radzenia sobie ze stresem będą negatywnie związane $\mathrm{z}$ radzeniem sobie przez humor.

H4: Założono, iż występuje bezpośredni związek pomiędzy radzeniem sobie przez humor a strategiami radzenia sobie ze stresem. Radzenie sobie przez humor będzie pozytywnie związane $\mathrm{z}$ adaptacyjnymi strategiami radzenia sobie i negatywnie związane ze strategiami dezadaptacyjnymi.

H5: Założono, iż występuje bezpośredni związek pomiędzy radzeniem sobie przez humor a poczuciem stresu. Osoby, które częściej będą wykorzystywały humor, aby poradzić sobie ze stresem, będą miały poczucie mniejszego stresu.

H6: Radzenie sobie przez humor będzie odgrywało rolę mediacyjną dla związku pomiędzy stylami radzenia sobie ze stresem a poczuciem stresu.

\section{METODA}

W badaniu wzięło udział łącznie 199 osób (113 kobiet i 86 mężczyzn) w wieku od 20 do 60 lat. Średnia wieku w grupie badanej wyniosła $\mathrm{M}=37,76(\mathrm{SD}=12,04)$. Kobiety $(\mathrm{M}=38,35 ; \mathrm{SD}=11,55)$ i mężczyźni $(\mathrm{M}=37,24$; $\mathrm{SD}=12,70)$ byli w podobnym wieku $(t=0,53 ; p=0,600)$. Badani ocenili swoje warunki socjalno-bytowe na skali od 0 do 10 na poziomie $\mathrm{M}=6,87(\mathrm{SD}=1,71)$, natomiast swoje zdrowie na poziomie $\mathrm{M}=7,52(\mathrm{SD}=1,65)$.

\section{Procedura badania}

Kryterium włączającym do grupy badanej było ukończenie 20. r.ż. oraz wykonywanie pracy zawodowej. Dobór do grupy badanej był celowy - wybierano osoby pracujące zawodowo, reprezentujące różne profesje. Wykorzystano metodę kuli śnieżnej do zbierania danych. Do badań wykorzystano pakiety kwestionariuszy, których kolejność w pakiecie była rotowana. Uczestnicy badania otrzymywali pakiet kwestionariuszy, zwracany po wypełnieniu $\mathrm{w}$ wyznaczonym terminie. Badania były prowadzone przez okres jednego miesiąca (przełom lutego i marca 2017 roku).

\section{Narzędzia badawcze}

W badaniach zastosowano następujące metody: Kwestionariusz Radzenia Sobie w Sytuacjach Stresowych (CISS), Inwentarz do Pomiaru Radzenia Sobie ze Stresem 
COPE Inventory, The Perception of Stress Questionnaire (Kwestionariusz Poczucia Stresu - KPS), Coping Humour Scale (CHS), and own questionnaire.

Coping Inventory for Stressful Situations (CISS) by Norman S. Endler and James D. Parker in the Polish adaptation by Piotr Szczepaniak, Jan Strelau and Kazimierz Wrześniewski [23] is used to study the style of coping with stress. This tool consists of 48 statements that relate to people's emotions and behaviours in difficult and stressful situations. The task of the respondent is to determine the frequency with which he or she shall undertake the action. The individual items form three sub-scales that define coping stress styles focused on task (TOC), emotion (EOC) and avoidance (AOC). Task-oriented coping style (TOC) defines a personality's tendency to cope with stress by actively trying to solve the problem. Emotion-oriented coping style (EOC) is coping with stress by focusing on one's own negative emotional experiences. Avoidance-oriented coping style (AOC) defines coping with stress by avoiding thinking, experiencing emotions and experiencing difficult, stressful situations. It can be further divided into two subscales, i.e. social diversion and distraction. In the conducted research, the CISS reliability, estimated on the basis of the Cronbach's alpha coefficient was as follows: 0.9 for TOC, 0.82 for EOC, 0.82 for AOC, 0.81 for social diversion and 0.76 for distraction.

Brief COPE by Charles S. Carver is an abbreviated version of the Multidimensional COPE Inventory (The Coping Orientations to Problems Experienced). The Polish adaptation of the tool by Zygfryd Juczyński and Nina Ogińska-Bulik [24] includes 28 theorems which are part of 14 coping strategies. These include: active coping, planning, positive reframing, acceptance, humour, religion, use of emotional support, use of instrumental support, self-distraction, denial, substance use, behavioural disengagement and self-blame. The higher the score, the more often the respondent applies the strategy. In the conducted research, the reliability estimated on the Cronbach's alpha coefficient for particular sub-scales was as follows: 0.5 for active coping; 0.67 for planning; 0.72 for positive reframing; 0.37 for acceptance; 0.59 for humour; 0.8 for religion; 0.81 for use of emotional support; 0.74 for use of instrumental support; 0.38 for self-distraction; 0.6 for denial; 0.67 for venting; 0.93 for substance use; 0.61 for behavioural disengagement; 0.63 for self blame. Because of such diversified reliability, only those strategies for which Cronbach's alpha was greater than 0.7 were included in the analysis.

The Perception of Stress Questionnaire (KPS) by Mieczysław Plopa and Ryszard Makarowski [25] is designed to measure the structure of a person's stress sensations. It consists of 27 statements, which form three
Mini-COPE, Kwestionariusz Poczucia Stresu (KPS), Skalę Radzenia Sobie przez Humor (CHS) oraz ankietę własną.

Kwestionariusz Radzenia Sobie w Sytuacjach Stresowych (Coping Inventory for Stressful Situations - CISS) autorstwa Normana S. Endlera i Jamesa D. Parkera w polskiej adaptacji Piotra Szczepaniaka, Jana Strelaua i Kazimierza Wrześniewskiego [23] służy do badania stylów radzenia sobie ze stresem. Narzędzie składa się z 48 stwierdzeń, które dotyczą emocji i zachowań ludzi w odpowiedzi na trudne, stresujące sytuacje. Zadaniem osoby badanej jest określić częstotliwość, z jaką podejmuje dane działanie. Poszczególne itemy tworzą trzy podskale określające style radzenia sobie ze stresem, skoncentrowane na: zadaniu (SSZ), emocjach (SSE) oraz unikaniu (SSU). Styl skoncentrowany na zadaniu (SSZ) określa tendencję osobowościową do radzenia sobie ze stresem polegającą na aktywnym podejmowaniu próby rozwiązania problemu. Styl skoncentrowany na emocjach (SSE) dotyczy radzenia sobie ze stresem polegającego na koncentracji na własnych, negatywnych przeżyciach emocjonalnych. Styl skoncentrowany na unikaniu (SSU) określa radzenie sobie ze stresem polegające na wystrzeganiu się myślenia, przeżywania emocji, a także doświadczania trudnych, stresujących sytuacji. Może przyjmować dwie formy: poszukiwania kontaktów towarzyskich (podskala PKT) lub angażowania się w czynności zastępcze (podskala ACZ). W przeprowadzonych badaniach rzetelność CISS szacowana na podstawie współczynnika alfa Cronbacha wynosiła: 0,90 dla SSZ, 0,82 dla SSE, 0,82 dla SSU, 0,81 dla PKT oraz 0,76 dla ACZ.

Inwentarz do Pomiaru Radzenia Sobie ze Stresem Mini-COPE autorstwa Charlesa S. Carvera stanowi skróconą wersję Wielowymiarowego Inwentarza do Pomiaru Radzenia Sobie ze Stresem (The Coping Orientations to Problems Experienced - COPE). Polska adaptacja narzędzia, którego autorami są Zygfryd Juczyński i Nina Ogińska-Bulik [24] obejmuje 28 twierdzeń wchodzących w skład 14 strategii radzenia sobie. Należą do nich: aktywne radzenie sobie, planowanie, pozytywne przewartościowanie, akceptacja, poczucie humoru, zwrot ku religii, poszukiwanie wsparcia emocjonalnego, poszukiwanie wsparcia instrumentalnego, zajmowanie się czymś innym, zaprzeczanie, wyładowanie, zażywanie substancji psychoaktywnych, zaprzestanie działań, obwinianie siebie. Im wyższa punktacja, tym częściej badana osoba stosuje daną strategię. $\mathrm{W}$ przeprowadzonych badaniach rzetelność szacowana na podstawie współczynnika alfa Cronbacha dla poszczególnych podskal wynosiła: 0,50 dla aktywnego radzenia sobie, 0,67 dla planowania, 0,72 dla pozytywnego przewartościowania, 0,37 dla akceptacji, 0,59 dla poczucia humoru, 0,80 dla zwrotu ku religii, 0,81 dla poszukiwania wsparcia emocjonalnego, 0,74 dla poszukiwania wsparcia instrumentalnego, 0,38 dla zajmowania się czymś innym, 0,60 dla zaprzeczania, 0,67 dla wyładowania, 0,93 dla zażywania substancji psychoaktywnych, 0,61 dla zaprzestania działań, 0,63 dla obwiniania siebie. W związku z tak zróżnicowaną rzetelnością do analiz włączono tylko te strategie, dla których alfa Cronbacha było większe od 0,70. 
subscales: emotional tension (anxiety, excessive nervousness, sense of fatigue with no apparent reason), external stress (sense of being unfairly assessed by other persons in various social contexts), and intrapsychic stress (concerns, worries, pessimistic views of life because of experiencing difficulties in achieving goals). It is possible to calculate an overall result informing about the stress level. The responders' task is to answer the question to what extend particular claims concern them by responding to them on a five-stage scale. In the conducted studies, the reliability of KPS, estimated on the basis of Cronbach's alpha for the total result was 0.84 . For the individual subscales it was 0.79 for emotional tension, 0.71 for external stress and 0.76 for intrapsychic stress.

Coping Humour Scale (CHS) by R.A. Martin and Herbert M. Lefcourt [18] in Polish adaptation by Agnieszka Kruczek and Małgorzata A. Basińska. Coping Humour Scale is a self-descriptive scale in which the respondent rates the degree of intensity of humour response behaviour in stressful situations. The CHS consists of 7 items about the use of humour in coping with stress. Respondents rate the degree to which each statement describes them on a scale from 1 - strongly disagree to 4 - strongly agree. The first and fourth positions' values are opposite. The higher the CHS score, the more often an individual copes with stressful situations through humour. The score that can be obtained by the responder is between 7 and 28 .

The authors of the scale demonstrated internal consistency of the CHS scale measured on the basis of Cronbach's alpha at the level of 0.61 [18]. On the other hand, the convergent validity studies showed correlations between the Coping Humour Scale and the results of other humour research tools. The relations between the CHS scale and two subscales of the Sense of Humour Questionnaire (SHQ) with correlation coefficients of 0.51 and 0.33 and the results of the Situational Humour Response Questionnaire (SHRQ) at the level of 0.37 was proved. Studies performed so far, using this scale, indicate reliability within the range from 0.6 to $0.8[18,27]$.

In the Polish version of CHS, the 4th position of the scale, which had the lowest correlation with the overall score, was removed. The reliability of the 6-item CHS scale measured on the basis of Cronbach's alpha was at 0.72 . The Coping Humour Scale, therefore, meets the Nunnaly criterion, which requires the tool to be considered a reliable scale when the Cronbach's alpha value exceeds 0.7. In the case of the Polish version of CHS the factorial charges ranged from 0.46 to 0.82 . The drawn factor explains $55.22 \%$ of the common variance.
Kwestionariusz Poczucia Stresu (KPS) autorstwa Mieczysława Plopy i Ryszarda Makarowskiego [25] przeznaczony jest do pomiaru struktury doznań stresowych odczuwanych przez osobę. Składa się z 27 stwierdzeń, które tworzą trzy podskale: napięcia emocjonalnego (poczucie niepokoju, nadmiernej nerwowości, często odczuwane zmęczenie bez wyraźnej przyczyny), stresu zewnętrznego (poczucie bycia niesprawiedliwie ocenianym przez inne osoby w różnych kontekstach społecznych) oraz stresu intrapsychicznego (to m.in.: obawy, zamartwianie się, obniżone poczucie sensu życia z powodu odczuwania trudności w realizacji celów). Możliwe jest obliczenie wyniku ogólnego informującego o poziomie stresu. Zadaniem badanego jest udzielenie odpowiedzi na pytanie, w jakim stopniu poszczególne twierdzenia go dotyczą. Ustosunkowuje się do nich na pięciostopniowej skali. W przeprowadzonych badaniach rzetelność KPS szacowana na podstawie współczynnika alfa Cronbacha dla wyniku ogólnego wynosiła 0,84 . Natomiast dla poszczególnych podskal: 0,79 dla napięcia emocjonalnego, 0,71 dla stresu zewnętrznego oraz 0,76 dla stresu intrapsychicznego.

Skala Radzenia Sobie przez Humor (Coping Humour Scale - CHS) autorstwa R.A. Martina i Herberta M. Lefcourta [18] w polskiej adaptacji Agnieszki Kruczek i Małgorzaty A. Basińskiej. Skala Radzenia Sobie przez Humor jest skalą samoopisową, w której badany określa stopień nasilenia zachowań polegających na reagowaniu humorem w sytuacjach stresujących. Kwestionariusz składa się z 7 itemów dotyczących radzenia sobie za pomocą humoru. Badani udzielają odpowiedzi na czterostopniowej skali: od 1 (zdecydowanie nie zgadzam się ze stwierdzeniem) do 4 (zdecydowanie się zgadzam). Pozycja pierwsza i czwarta liczone są odwrotnie. Im wyższy wynik w skali CHS, tym osoba w większym stopniu radzi sobie ze stresującymi sytuacjami, wykorzystując humor. Wynik punktowy, który badany może uzyskać, mieści się w przedziale od 7 do 28.

Autorzy skali wykazali spójność wewnętrzną skali CHS mierzoną za pomocą współczynnika alfa Cronbacha na poziomie 0,61 [18]. Natomiast w badaniach trafności zbieżnej wykazano korelacje pomiędzy Skalą Radzenia Sobie przez Humor oraz wynikami innych narzędzi badających humor. Dowiedziono związki pomiędzy skalą CHS a dwiema podskalami Kwestionariusza Poczucia Humoru o współczynnikach korelacji 0,51 i 0,33 oraz wynikami w Situational Humor Response Questionnaire na poziomie 0,37. Wykonane dotychczas badania przy zastosowaniu tej skali wskazują na rzetelność w granicach od 0,60 do 0,80 [18, 27].

W polskiej wersji CHS usunięto czwartą pozycję skali, która najniżej korelowała z wynikiem ogólnym. Rzetelność 6-itemowej skali CHS mierzona za pomocą współczynnika alfa Cronbacha wynosiła 0,72. Skala Radzenia Sobie przez Humor spełnia zatem kryterium Nunnaly’ego wymagające, aby narzędzie uznać za rzetelną skalę, gdy wartość alfa Cronbacha przekracza 0,70 . W przypadku polskiej wersji CHS ładunki czynnikowe zawierały się w przedziałach od 0,46 do 0,82 . Wyłoniony czynnik wyjaśnia 55,22\% wariancji wspólnej. 
Table 1. Differences in coping humour according to gender and age

Tabela 1. Różnice w zakresie radzenia sobie przez humor ze względu na płeć i wiek

\begin{tabular}{|c|c|c|c|c|c|}
\hline \multirow{2}{*}{$\begin{array}{l}\text { Variable independent/ } \\
\text { Zmienna niezależna }\end{array}$} & \multirow{2}{*}{$\begin{array}{l}\text { Number }(n) / \\
\text { Liczebność }(n)\end{array}$} & \multicolumn{2}{|c|}{ Humour coping/Radzenie sobie przez humor } & \multicolumn{2}{|c|}{ Difference/Różnica } \\
\hline & & $\begin{array}{l}\text { mean/ } \\
\text { średnia }\end{array}$ & $\begin{array}{l}\text { standard deviation/ } \\
\text { odchylenie standardowe }\end{array}$ & $\begin{array}{l}\text { Student's } t / \\
t \text { Studenta }\end{array}$ & $\begin{array}{l}\text { significance }(p) / \\
\text { istołność }(p)\end{array}$ \\
\hline \multicolumn{6}{|l|}{ Gender/Płeć } \\
\hline males/mężczyźni & 86 & 17.55 & 3.25 & \multirow{2}{*}{-3.06} & \multirow{2}{*}{0.002} \\
\hline females/kobiety & 113 & 16.04 & 3.67 & & \\
\hline \multicolumn{6}{|c|}{ Age: adulthood/Wiek: dorosłość } \\
\hline early/wczesna & 104 & 16.14 & 3.40 & \multirow{2}{*}{-2.21} & \multirow{2}{*}{0.029} \\
\hline average/ środkowa & 95 & 17.27 & 3.60 & & \\
\hline
\end{tabular}

In order to obtain information on socio-demographic data, an own questionnaire was used.

All statistical analyses were performed with the use of Statistica version 12 software. Only subscales with satisfactory Cronbach's alpha coefficient, i.e. above 0.7 were included in the analysis.

\section{RESULTS}

\section{Differences in coping humour according to gender and age of responders}

The analysis of the obtained results shows that there are statistically significant differences in the intensity of the use of humour coping between women and men. Women are significantly less likely to cope with stress through humour than men (Table 1).

In literature, one can find various approaches to periodisation of adulthood. The research focused on the Helen Bee's division of adulthood [25] into early adulthood (from 20 to 40 years), average adulthood (from 40 to 60 years) and late adulthood (over 60 years). Taking into account this demographic variable, the respondents were divided into two groups:

1. Early adulthood (from 20 to 40 years), $\mathrm{N}=104$ (52\%).

2. Average adulthood (from 40 to 60 years), $\mathrm{N}=95$ (48\%).

There were statistically significant differences in the use of humour coping due to the period of adulthood in which the responders currently are. Individuals in early adulthood were less likely to use humour coping that those in middle adulthood (Table 1).

At the next stage of the analysis about the differences in the range of humour coping, both gender and age were taken into account. The results show that age-related differences in humour coping are similar for both genders. Older people cope with stress through humour to a wider extent both among women and men $(\mathrm{F}=0.67 ; p=0.515$; $\left.\eta^{2}=0.01\right)$.
W celu uzyskania informacji dotyczących danych społeczno-demograficznych wykorzystano ankietę własną.

Wszelkie analizy statystyczne wykonano za pomocą oprogramowania Statistica wersja 12. Do analiz włączono jedynie podskale o zadowalającym współczynniku alfa Cronbacha, czyli powyżej 0,70 .

\section{WYNIKI}

\section{Różnice w zakresie radzenia sobie przez humor ze względu na charakterystyki badanych (płeć, wiek)}

Na podstawie analizy uzyskanych wyników stwierdza się występowanie istotnych statystycznie różnic $\mathrm{w}$ nasileniu stosowania radzenia sobie przez humor pomiędzy kobietami i mężczyznami. Kobiety w istotnie mniejszym stopniu stosują radzenie sobie ze stresem poprzez humor niż mężczý́ni (tab. 1).

W literaturze przedmiotu można znaleźć zróżnicowane ujęcia periodyzacji dorosłości. W przeprowadzonych badaniach skoncentrowano się na podziale dorosłości w ujęciu Helen Bee [25]: na wczesny okres dorosłości (20-40 lat), środkowy okres dorosłości (40-60 lat) oraz późny okres dorosłości (od 60 lat). Mając na uwadze tę zmienną demograficzną, podzielono badanych na dwie grupy:

1. Wczesna dorosłość (20-40 lat), $\mathrm{N}=104$ (52\%).

2. Środkowa dorosłość (40-60 lat), N = 95 (48\%).

Stwierdzono występowanie istotnych statystycznie różnic w zakresie stosowania radzenia sobie przez humor ze względu na okres dorosłości, w jakim badani się aktualnie znajdują. Osoby we wczesnej dorosłości rzadziej stosowały radzenie sobie przez humor niż osoby będące na etapie średniej dorosłości (tab. 1).

W następnym etapie analiz dotyczących zróżnicowań w zakresie radzenia sobie ze stresem przez humor uwzględniono zarówno płeć badanych, jak i wiek. Uzyskane wyniki wskazują, że różnice w zakresie radzenia sobie ze stresem przez humor związane $\mathrm{z}$ wiekiem są podobne dla obu płci. Osoby starsze w większym zakresie radzą sobie ze stresem przez humor zarówno w grupie kobiet, jak i mężczyzn $\left(\mathrm{F}=0,67 ; p=0,515 ; \eta^{2}=0,01\right)$. 
Humour, stress and coping in adults

Humor, stres i radzenie sobie z nim u ludzi dorosłych

Table 2. Relationships between coping styles, strategies, sense of stress and humour coping

Tabela 2. Związki stylów radzenia sobie ze stresem, strategii oraz poczucia stresu z radzeniem sobie przez humor

\begin{tabular}{|c|c|c|}
\hline \multirow{2}{*}{ Correlated variables/Korelowane zmienne } & \multicolumn{2}{|c|}{ Humour coping/Radzenie sobie przez humor } \\
\hline & $r$ & $p$ \\
\hline \multicolumn{3}{|l|}{ Coping stress styles/Style radzenia sobie ze stresem } \\
\hline task-oriented coping style/styl skoncentrowany na zadaniu & 0.23 & 0.001 \\
\hline emotion-oriented coping style/styl skoncentrowany na emocjach & -0.35 & $<0.001$ \\
\hline avoidance-oriented coping style/styl skoncentrowany na unikaniu & 0.11 & 0.110 \\
\hline distraction/czynności zastępcze & 0.04 & 0.584 \\
\hline social diversion/poszukiwanie kontaktów towarzyskich & 0.10 & 0.175 \\
\hline \multicolumn{3}{|l|}{ Coping strategies/Strategie radzenia sobie } \\
\hline positive reframing/pozytywne przewartościowanie & 0.38 & $<0.001$ \\
\hline religion/zwrot ku religii & -0.04 & 0.650 \\
\hline use of emotional support/poszukiwanie wsparcia emocjonalnego & 0.17 & 0.032 \\
\hline use of instrumental support/poszukiwanie wsparcia instrumentalnego & 0.10 & 0.198 \\
\hline substance use/zażywanie substancji psychoaktywnych & 0.11 & 0.156 \\
\hline \multicolumn{3}{|l|}{ Perception of stress/Poczucie stresu } \\
\hline emotional tension/napięcie emocjonalne & -0.35 & $<0.001$ \\
\hline external stress/stres zewnętrzny & -0.28 & $<0.001$ \\
\hline intrapsychic stress/stres intrapsychiczny & -0.23 & 0.003 \\
\hline perception of stress - sum/poczucie stresu - suma & -0.32 & $<0.001$ \\
\hline
\end{tabular}

$r$ - Pearson's linear correlation coefficient/współczynnik korelacji liniowej Pearsona; $p$-statistical significance level/poziom istotności statystycznej

\section{Relations between humour coping and coping stress styles}

Studies have shown that there are statistically significant relations between humour coping and coping stress style, such as task-oriented coping style and emotional-oriented coping style. The more often people used task-oriented coping style, and the less often they used emotion-oriented coping style, their coping with humour-conscious stress was better. No statistically significant relations were found between the avoidance-oriented coping style or its subscales and the humour coping strategy (Table 2).

\section{Relations between humour coping and coping stress strategies}

Data analyses showed that there are statistically significant relations between humour coping and a positive reframing coping strategy. The more often the responders coped with stress through humour, the more often they used the positive reframing and reinterpretation coping strategy. Other coping strategies did not correlate at a statistically significant level with humour coping (Table 2).

\section{Związki pomiędzy radzeniem sobie przez humor a stylami radzenia sobie ze stresem}

Analizy wykazały występowanie istotnych statystycznie związków pomiędzy radzeniem sobie przez humor a stylami radzenia sobie ze stresem, takimi jak styl skoncentrowany na zadaniu i styl skoncentrowany na emocjach. Im częściej osoby wykorzystywały styl skoncentrowany na zadaniu w radzeniu sobie, a w mniejszym stopniu styl skoncentrowany na emocjach, tym częściej radziły sobie ze stresem przez humor. Nie stwierdzono związków istotnych statystycznie między stylem skoncentrowanym na unikaniu i jego podstylami a strategią radzenia sobie przez humor (tab. 2).

\section{Związi pomiędzy radzeniem sobie przez humor a strategiami radzenia sobie ze stresem}

Analizy danych wykazały występowanie istotnych statystycznie związków pomiędzy radzeniem sobie przez humor a strategią radzenia sobie ze stresem - pozytywne przewartościowanie. Im częściej badani radzili sobie ze stresem przez humor, tym częściej wykorzystywali strategię radzenia sobie ze stresem polegającą na pozytywnym przewartościowaniu i reinterpretacji. Pozostałe strategie radzenia sobie nie korelowały na poziomie istotnym statystycznie z radzeniem sobie przez humor (tab. 2). 


\section{Relation between humour coping and sense of stress}

Analyses show that there are statistically significant relations between humour coping and sense of stress. The more often the responders used humour to cope with stress, the less they presented a sense of stress expressed in lower emotional tension, lower sense of external stress and lower sense of intrapsychic stress (Table 2).

\section{Relation between coping with stress style and sense of stress - the intermediary role of humour coping}

A statistical reasoning procedure developed by Reuben Baron and David Kenny was used to solve the issue of mediating through humour coping between coping stress styles and sense of stress [28]. The procedure aims to show that an independent variable (coping stress style) is a mediator's predictor - humour coping (path a), a mediator is a predictor of a dependent variable (sense of stress) in the independent variable control (path b), and an independent variable is a predictor of a dependent variable in the mediator control (path c'). In addition, the direct influence of an independent variable on a dependent variable without the participation of a mediator is tested (path c). In order to speak of the occurrence of mediation, the conditions of statistical significance of $\beta$ value of paths $a$ and $b$ must be met (obligatory condition).

In a model that takes into account the role of task-oriented coping style and humour coping ( $\left.c^{\prime}\right)$ at the same time, the role of task-oriented coping style was statistically insignificant $(\beta=-0.13 ; p=$ n.s. $)$. Therefore, humour coping mediates the relation between the task-oriented coping style and the sense of stress. People who prefer this style of coping with stress had lower sense of stress thanks to using humour more often.

On the other hand, in a model that takes into account the role of emotion-oriented coping style and humour coping $\left(c^{\prime}\right)$ at the same time, the role of emotion-oriented coping style decreased, but remained statistically significant $(\beta=0.40 ; p<0.001)$. Therefore, in order to check if the change of $\beta$ value is significantly high, a Sobel test was performed, the results of which showed that there is no partial mediation of humour coping $(z=3.33$; $p=$ n.s. $)$ between the emotion-oriented coping style and the sense of stress (Figure I).

\section{DISCUSSION}

The reason for undertaking research into humour coping and its relations to coping stress styles and strategies as well as sense of stress was to consider

\section{Zwiq̨zek pomiędzy radzeniem sobie przez humor a poczuciem stresu}

Na podstawie analiz można stwierdzić występowanie istotnych statystycznie związków pomiędzy radzeniem sobie przez humor a poczuciem stresu. Im częściej badani wykorzystywali humor, aby poradzić sobie ze stresem, tym mniejsze prezentowali poczucie stresu wyrażające się w mniejszym napięciu emocjonalnym, poczuciu mniejszego stresu zewnętrznego oraz mniejszym poczuciu stresu intrapsychicznego (tab. 2).

\section{Związek pomiędzy stylami radzenia sobie ze stresem a poczuciem stresu - mediacyjna rola radzenia sobie przez humor}

W celu rozwiązania problemu badawczego dotyczącego mediowania przez radzenie sobie przez humor związku pomiędzy stylami radzenia sobie ze stresem a poczuciem stresu, wykorzystano procedurę wnioskowania statystycznego opracowaną przez Reubena Barona i Davida Kenny'ego [28]. Procedura ma na celu wykazanie, że zmienna niezależna (styl radzenia sobie ze stresem) jest predyktorem mediatora - radzenia sobie przez humor (ścieżka a), mediator jest predyktorem zmiennej zależnej (poczucia stresu) przy kontroli zmiennej niezależnej (ścieżka b), a zmienna niezależna jest predyktorem zmiennej zależnej przy kontroli mediatora (ścieżka c'). Ponadto testowany jest bezpośredni wpływ zmiennej niezależnej na zmienną zależną bez udziału mediatora (ścieżka c). Aby można było mówić o wystąpieniu mediacji, muszą zostać spełnione warunki istotności statystycznej wartości $\beta$ ścieżek a i b (warunek obligatoryjny).

$\mathrm{W}$ modelu uwzględniającym jednocześnie rolę stylu skoncentrowanego na zadaniu oraz radzenia sobie przez humor (c') rola stylu skoncentrowanego na zadaniu okazała się nieistotna statystycznie $(\beta=-0,13 ; p=$ n.i.). Zatem radzenie sobie przez humor mediuje związek pomiędzy stylem skoncentrowanym na zadaniu w radzeniu sobie ze stresem a poczuciem stresu. Osoby, które preferują ten styl radzenia sobie ze stresem, przez częstsze stosowanie humoru miały mniejsze poczucie stresu.

Natomiast w modelu uwzględniającym zarówno rolę stylu skoncentrowanego na emocjach, jak i radzenia sobie przez humor (c') rola stylu skoncentrowanego na emocjach zmalała, jednak pozostała nadal istotna statystycznie $(\beta=0,40 ; p<0,001)$. Wobec powyższego, $\mathrm{w}$ celu sprawdzenia, czy zmiana współczynnika $\beta$ jest istotnie wysoka, przeprowadzono test Sobela, którego wyniki wykazały, że nie zachodzi częściowa mediacja radzenia sobie przez humor $(z=3,33 ; p=$ n.i.) pomiędzy stylem skoncentrowanym na emocjach a poczuciem stresu (ryc. I).

\section{DYSKUSJA}

Powodem podjęcia badań dotyczących radzenia sobie przez humor i jego związków z radzeniem sobie ze stresem w postaci stylów, strategii i poczucia stresu było 


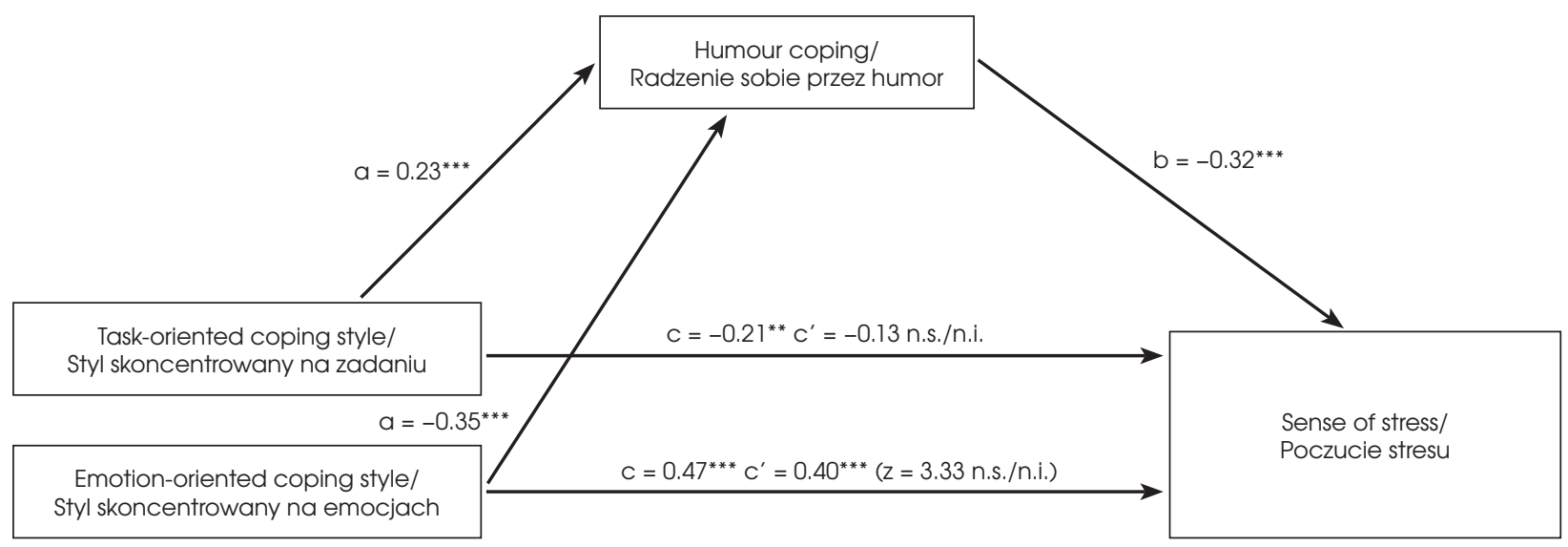

${ }^{*} p<0.05 ;{ }^{* *} p<0.01 ;{ }^{* * *} p<0.001 ;$ n.s./n.i. - not statistically significant/nieistotne statystycznie

Figure I. Coping with stress styles and a sense of stress - the mediating role of humour coping

Rycina I. Style radzenia sobie ze stresem a poczucie stresu - mediacyjna rola radzenia sobie przez humor

humour as an important resource in coping with stress and as an important support for maintaining health. In light of the research conducted so far, the use of humour changes the levels of cortisol and catecholamines, and therefore secondary affects the more effective functioning of the immune system [11]. Secondly, laughter increases the level of oxygenation in the body, raises the level of endorphins and has a positive effect on heart rate [22]. Humour causes positive emotions, which improves the general condition of the body and may even have analgesic effects [8]. The choice of early and middle adulthood working people was dictated by the fact that the studies conducted on humour coping around the world focused mainly on groups of students, who are most often at the stage of early adulthood [3, 10]. Moreover, so far no research on humour coping using the Coping Humour Scale by Martin and Lefcourt has been carried out in Poland [18].

Hypothesis 1 was positively verified. Studies have shown that women cope with stress through humour to a lower extent than men. In the context of the research on humour styles conducted by Elżbieta Hornowska and Jolanta Charytonik [6], men were more inclined than women to use aggressive humour. In Martin's research [3], men achieved significantly higher results compared to women in all dimensions of humour: affiliative, self-enhancing, aggressive, and self-defeating. This can be explained by the different tendencies of women and men to cope with stress. In light of the results of the study, in the face of stressful situations women were more likely than men to seek social contacts [30]. They are likely to use their contacts with other people to get social support. This can indirectly lead to experiences of coping with a difficult uznanie humoru za istotny zasób osobisty w radzeniu sobie ze stresem, stanowiący ważne wsparcie dla utrzymania zdrowia. W świetle dotychczas przeprowadzonych badań stosowanie humoru zmienia poziom kortyzolu i katecholamin, w związku z czym wpływa wtórnie na bardziej efektywne funkcjonowanie układu immunologicznego [11]. Ponadto śmiech zwiększa poziom dotlenienia organizmu, podnosi poziom endorfin oraz wpływa pozytywnie na pracę serca [22]. Humor wywołuje pozytywne emocje, co poprawia ogólną kondycję organizmu i może mieć nawet działanie przeciwbólowe [8]. Wybór osób pracujących zawodowo we wczesnej i średniej dorosłości podyktowany był faktem, że dotychczasowe badania, które przeprowadzone zostały na świecie nad radzeniem sobie przez humor, skupiały się zasadniczo na grupach studentów, którzy znajdują się najczęściej na etapie wczesnej dorosłości $[3,10]$. Ponadto, na gruncie polskim nie wykonano żadnych badań na temat radzenia sobie przez humor z wykorzystaniem skali Coping Humour Scale, autorstwa Martina i Lefcourta [18].

Hipoteza 1 została zweryfikowana pozytywnie. Przeprowadzone badania wykazały, że kobiety w mniejszym stopniu radzą sobie ze stresem poprzez humor niż mężczyźni. W kontekście badań nad stylami humoru, prowadzonymi przez Elżbietę Hornowską i Jolantę Charytonik [6], mężczyźni mieli większą skłonność niż kobiety do posługiwania się humorem agresywnym. W badaniach Martina [3] mężczyźni uzyskali istotnie wyższe wyniki w porównaniu z kobietami we wszystkich wymiarach humoru: afiliacyjnym, w służbie ego, agresywnym i samodeprecjonującym. Fakt ten można tłumaczyć zróżnicowanymi tendencjami kobiet i mężczyzn w zakresie radzenia sobie ze stresem w ogóle. W świetle wyników badań, w obliczu sytuacji stresującej kobiety częściej niż mężczyźni poszukiwały kontaktów towarzyskich [30]. Przypuszczalnie mogą wykorzystywać kontakty z innymi ludźmi w celu uzyskiwania wsparcia społecznego. To pośred- 
situation and alleviating mental tension, as well as receiving guidance from other people on how to solve a difficult situation.

Hypothesis 2 was also positively verified. According to the research, people in early adulthood were less likely to use humour coping than the elderly. Humour coping is considered to be a mature strategy to deal with difficult situations. In light of the research conducted so far, humour was an effective strategy for older people to deal with age-related losses, especially when stressful events could not be controlled [31]. It can be assumed that the life experience of older people allowed them to further distance themselves and to take a more humorous perspective in the face of stressful situations. This way of using humour makes it possible to see stressful stimuli more as a challenge than a threat.

Hypothesis 3 was verified partially positively. In light of the own conducted research individuals who more often used task-oriented coping style, and less often emotion-oriented coping style, more often were using the humour coping. Herbert M. Lefcourt et al. [19] proposed two types of humour related strategies One of them is the emotional-oriented coping strategy used as a defensive remedy. In this strategy, humour is used in the face of a stressful event to reduce a negative emotional reaction. The other one is the problem-oriented strategy where humour is used to change the stressful situation itself as a support for the defensive mechanism of an emotion-oriented strategy. The results of in-depth analyses have shown that coping with humour mediates the relationship between the task-focused coping style and a sense of stress. Individuals who prefer task-oriented coping style, i.e. they undertake active attempts to solve the problem, by more frequent use of humour coping have lower sense of stress. Hypothesis 6 was verified partially positively.

Literature of subject contains a group of studies which prove that the use of humour is in the same group as dysfunctional, maladaptive coping strategies, i.e. running away, distancing oneself, avoiding the problem, denial, substance use, mental and behavioural disengagement [14]. In light of own conducted research, people who were more likely to cope with stress through humour used positive reframing coping strategy, which to a wider extent - is an adaptive coping strategy. Therefore hypothesis 4 was verified partially positively. In light of other research, people who more frequently responded with laughter preferred coping strategies, such as reframing or facing a difficult situation $[14,21]$. It may be assumed that in the context of a stressful situation, humour positively influences the assessment of stress and weakens the negative affective response [14]. The basis of such an understanding of the mechanism nio może prowadzić do uzyskania doświadczeń radzenia sobie $\mathrm{z}$ trudną sytuacją i niwelowania napięcia psychicznego, jak również otrzymywania dzięki innym ludziom wskazówek na temat rozwiązania sytuacji trudnej.

Także hipoteza 2 została zweryfikowana pozytywnie. W świetle przeprowadzonych badań osoby we wczesnej dorosłości rzadziej radziły sobie przez humor niż osoby starsze. Radzenie sobie przez humor uznawane jest za dojrzałą strategię radzenia sobie $\mathrm{z}$ sytuacjami trudnymi. W świetle wyników dotychczas przeprowadzonych badań humor stanowił dla osób starszych efektywną strategię radzenia sobie ze stratą związaną z wiekiem, w szczególności kiedy stresujące wydarzenie nie było możliwe do kontrolowania [31]. Można przypuszczać, że bogatsze doświadczenie życiowe osób starszych pozwoliło im na większe dystansowanie się oraz przyjmowanie bardziej humorystycznej perspektywy w obliczu sytuacji stresujących. Taki sposób posługiwania się humorem umożliwia postrzeganie bodźców stresogennych bardziej jako wyzwanie niż zagrożenie.

Hipoteza 3 została zweryfikowana częściowo pozytywnie. W świetle przeprowadzonych badań własnych osoby, które częściej wykorzystywały styl skoncentrowany na zadaniu w radzeniu sobie w sytuacjach stresowych a w mniejszym stopniu styl skoncentrowany na emocjach, częściej radzily sobie ze stresem przez humor. Herbert M. Lefcourt i wsp. [19] wysunęli propozycję dwóch typów strategii związanych $\mathrm{z}$ humorem. Pierwszy z nich - skoncentrowana na emocjach strategia radzenia sobie jako środek obronny. $\mathrm{W}$ tym typie humor stosowany jest $\mathrm{w}$ sytuacji stresującej i ma na celu obniżenie negatywnej reakcji emocjonalnej. Drugi typ - strategia skoncentrowana na problemie, w której humor jest wykorzystywany $\mathrm{w}$ celu zmiany sytuacji stresującej samej w sobie jako wsparcie dla defensywnego mechanizmu strategii radzenia sobie skoncentrowanej na emocjach. Wyniki pogłębionych analiz pozwoliły na stwierdzenie, że radzenie sobie przez humor mediuje związek pomiędzy stylem skoncentrowanym na zadaniu a poczuciem stresu. Osoby, które preferują styl radzenia sobie ze stresem skoncentrowany na zadaniu, a więc podejmują aktywne próby rozwiązania problemu przez częstsze stosowanie humoru, miały mniejsze poczucie stresu. Hipoteza 6 została zweryfikowana częściowo pozytywnie.

W literaturze przedmiotu znaleźć można grupę badań, które dowodzą, że wykorzystanie humoru znajduje się w tej samej grupie co dysfunkcjonalne, nieadaptacyjne strategie radzenia sobie ze stresem przez ucieczkę, dystansowanie się, unikanie problemu, zaprzeczanie, sięganie po alkohol/narkotyki, psychiczne i behawioralne wycofanie [14]. W świetle przeprowadzonych badań własnych osoby, które częściej radziły sobie ze stresem przez humor, w szerszym zakresie wykorzystywały strategię radzenia sobie ze stresem polegającą na pozytywnym przewartościowaniu. Jest ona adaptacyjną strategią radzenia sobie. Zatem hipoteza 4 została zweryfikowana częściowo pozytywnie. $\mathrm{W}$ świetle innych badań osoby, które częściej reagowały 
of humour influence over the coping with stress is the cognitive-transactional theory of stress by Lazarus and Folkman [5].

Research of Ewa Rieger and Alicja McGrail [27] confirmed that this humorous perspective is the key to the development of adaptive coping strategies. Use of humour is associated with taking action to solve a problem that causes stress. Yalom Rim [32] pointed out statistically significant relations between the various forms of humour and defensive mechanism, such as minimisation, which he described as finding positive sides, or reversing, i.e. looking for something funny in a stressful situation.

Numerous research show that people who used humour to cope with stress more often were more emotionally stable; they more effectively regulated their emotions and behaviours and were in a better mental health. The cause of that situation was the frequent use of humour to re-assess stress as less threatening. As a result, they coped with stress more effectively $[14,16,18,19,26]$. In light of the conducted research, the more often the responders used humour to cope with stress, the less they presented a sense of stress expressed in; lower emotional tension, lower sense of external stress and lower sense of intrapsychic stress. Therefore hypothesis 5 was verified positively.

The results of our own research allow us to formulate practical implications. The use of humour in stressful situations can be a valuable subjective resource for coping with difficult situations more effectively. Cognitive and behavioural influences seem particularly valuable, as they include shaping a humorous perspective; using humour to relax; perceiving experiencing problems in a less threatening, humorous way, thus making them easier to solve. Raising people's awareness of the role of humour in coping with stress can also be important.

\section{Limitations of the carried out research}

The carried out research has certain limitations, which include the omission of the value of social support, which is an important element of the problem conceptualisation. In literature, individuals with a greater sense of humour are considered to be more sociable, with a richer network of social support. Hence, it is worth exploring the intermediary effects of social support on the relation between a sense of humour and a sense of stress. Such research would help to explain the mechanism of humour influence on more effective coping with stress.

To ensure statistical accuracy, the Brief-Cope subscales with their low reliability index were omitted from the analyses. Analyses based on them would certainly provide a broader picture of the relations between humour coping and both adaptive and active coping strategies. śmiechem, preferowały takie strategie radzenia sobie jak przewartościowanie czy konfrontacja $\mathrm{z}$ sytuacją trudną $[14,21]$. Można przypuszczać, iż w kontekście sytuacji stresującej humor pozytywnie wpływa na ocenę stresora i osłabia negatywną odpowiedź afektywną [14]. U podstaw takiego rozumienia mechanizmu oddziaływania humoru na radzenie sobie ze stresem leży poznawczo-transakcyjna teoria stresu Lazarusa i Folkman [5].

Badania Ewy Rieger i Alicji McGrail [27] potwierdzają, że taka humorystyczna perspektywa stanowi klucz dla rozwoju adaptacyjnych strategii radzenia sobie ze stresem. Zastosowanie humoru związane jest z podjęciem aktywności w celu rozwiązania problemu, który powoduje stres. Yalom Rim [32] wskazywał na istotne statystycznie związki pomiędzy różnymi formami humoru a mechanizmami defensywnymi, takimi jak minimalizacja, którą określał jako znajdowanie pozytywnych stron czy odwrócenie, czyli poszukiwanie czegoś zabawnego w stresującej sytuacji.

Liczne badania pokazują, że osoby, które częściej wykorzystują humor, aby radzić sobie ze stresem, były bardziej stabilne emocjonalnie, efektywniej regulowały emocje oraz zachowanie, były w lepszym zdrowiu psychicznym. Przyczyną takiego stanu rzeczy było częste wykorzystanie humoru w celu ponownej oceny stresora jako mniej zagrażającego. W rezultacie osoby te efektywniej radzą sobie ze stresem $[14,16,18,19,26]$. W świetle przeprowadzonych badań im osoby częściej wykorzystywały humor, aby poradzić sobie ze stresem, tym prezentowały mniejsze poczucie stresu wyrażające się w mniejszym napięciu emocjonalnym, w poczuciu mniejszego stresu zewnętrznego oraz mniejszym poczuciu stresu intrapsychicznego. Zatem hipoteza 5 została zweryfikowana pozytywnie.

Uzyskane wyniki przeprowadzonych badań własnych umożliwiają sformułowanie implikacji praktycznych. Stosowanie humoru w sytuacji stresu stanowić może cenny zasób podmiotowy, pozwalający efektywniej radzić sobie z sytuacjami trudnymi. Szczególnie wartościowe wydają się oddziaływania o charakterze poznawczo-behawioralnym, skupiające się m.in. na kształtowaniu humorystycznej perspektywy, wykorzystywaniu humoru w celu relaksacji, postrzeganiu doświadczanych problemów w sposób humorystyczny, mniej zagrażający, przez co łatwiej jest je rozwiązać. Istotne znaczenie może mieć także zwiększenie świadomości osób na temat roli stosowania humoru w radzeniu sobie ze stresem.

\section{Ograniczenia przeprowadzonych badań}

Przeprowadzone badania posiadają pewne ograniczenia, m.in. pominięcie waloru wsparcia społecznego, które jest istotnym elementem konceptualizacji problemu. W literaturze przedmiotu jednostki z większym poczuciem humoru uznaje się za bardziej towarzyskie, posiadające bogatszą sieć wsparcia społecznego. Stąd warto zbadać pośredniczący wpływ wsparcia społecznego na 


\section{CONCLUSIONS}

1. Women are less likely to use humour coping than men.

2. Individuals in early adulthood are less likely to use humour coping that those older than them.

3. Individuals who more often coped with stress through humour, more often used the adaptive positive reframing coping strategy.

4. Individuals who more often used task-oriented coping style and less often emotion-oriented coping style, more often were using the humour coping. Individuals who preferred task-oriented coping style and humour coping had lower sense of stress.

5. Individuals who used humour more often to cope with stress felt less stressed. związek pomiędzy poczuciem humoru a poczuciem stresu. Takie badania przyczyniłyby się do wyjaśnienia mechanizmu wpływu humoru na efektywniejsze radzenie sobie ze stresem.

$\mathrm{W}$ trosce o poprawność statystyczną pominięto w analizach podskale Mini-COPE o niskim wskaźniku rzetelności. Analizy z ich wykorzystaniem z pewnością pozwoliłyby na prezentację szerszego obrazu związków radzenia sobie przez humor $\mathrm{z}$ adaptacyjnymi oraz aktywnymi strategiami radzenia sobie ze stresem.

\section{WNIOSKI}

1. Kobiety rzadziej stosują radzenie sobie ze stresem przez humor niż mężczyźni.

2. Osoby we wczesnej dorosłości rzadziej stosują radzenie sobie przez humor niż osoby starsze.

3. Osoby, które częściej radziły sobie ze stresem przez humor, częściej wykorzystywały adaptacyjną strategię radzenia sobie ze stresem, polegającą na pozytywnym przewartościowaniu.

4. Osoby, które częściej wykorzystywały styl skoncentrowany na zadaniu a w mniejszym stopniu styl skoncentrowany na emocjach, częściej radziły sobie ze stresem przez humor. Osoby, które preferowały styl radzenia sobie ze stresem skoncentrowany na zadaniu, częściej wykorzystując humor, aby poradzić sobie ze stresem, miały mniejsze poczucie stresu.

5. Osoby, które częściej wykorzystywały humor, aby poradzić sobie ze stresem, miały mniejsze poczucie stresu.

\section{Conflict of interest/Konflikt interesu}

Absent./Nie występuje.

Financial support/Finansowanie

Absent./Nie występuje.

\section{References/Piśmiennicłwo}

1. Snyder CR, McCullough ME. A positive psychology field of dreams: "If you build it, they will come.... Journal of Social and Clinical Psychology 2000; 19: 151-160.

2. Ruch W, Carrell A. Trait cheerfulness and the sense of humour. Personality and Individual Differences 1998; 24: 551-558.

3. Martin RA. Sense of humor. In: Positive Psychological Assessment: A Handbook of Models and Measures. Lopez JS, Snyder CR (eds.). American Psychological Association: Washington; 2003, p. 313-326.

4. Feingold A, Mazzella R. Psychometric intelligence and verbal humor ability. Personality \& Individual Differences 1991; 12: 427-435.

5. Lazarus RS, Folkman S. Stress, Appraisal, and Coping. Springer: New York; 1984.

6. Hornowska E, Charytonik J. Polska adaptacja Kwestionariusza Stylów Humoru (HSQ) R. Martina, P. Puhlik-Doris, G. Larsena, J. Gray i K. Weir. Studia Psychologiczne 2011; 49: 5-22.

7. Seligman MEP, Csikszentmihalyi M. Positive psychology: An introduction. The American Psychologist 2000; 55: 5-14. 
8. Tomczuk-Wasilewska J. Psychologia humoru. Wydawnictwo KUL: Lublin; 2009.

9. Marshall GN, Wortman CB, Kusulas JW, Hervig LK, Vickers RR. Distinguishing optimism from pessimism: Relations to fundamental dimensions of mood and personality. Journal of Personality and Social Psychology 1992; 62: 1067-1074.

10. Martin RA. The psychology of humor: An integrative approach. Elsevier Academic Press: Burlington; 2007.

11. Martin RA. Humor, Laughter, and Physical Health: Methodological Issues and Research Findings. Psychological Bulletin 2001; 127: 504-519.

12. Freud S. Humour. International Journal of Psychoanalysis 1928; 9: 1-6.

13. Suls JM. Cognitive processes in humor appreciation. In: Handbook of humor research. Vol. 1: Basic issues. McGhee PE, Goldstein JH (eds.). Springer-Verlag: New York; 1983, p. 39-57.

14. Kuiper NA, Martin RA, Olinger LJ. Coping humour, stress, and cognitive appraisals. Canadian Journal of Behavioural Science 1993; 25: 81-96.

15. Lefcourt HM. The humor solution. In: Coping with stress: Effective people and processes. Snyder CR (eds.). Oxford University Press: New York, NY; 2001, p. 68-92.

16. Lefcourt HM, Martin RA. Humor and life stress: Antidote to adversity. Springer-Verlag: New York; 1986.

17. Sutherland M. False Alarm Theory: How Humorous Ads Work 2005 (online).

18. Martin RA, Lefcourt HM. Sense of humor as a moderator of the relation between stressors and moods. Journal of Personality \& Social Psychology 1983; 45: 1313-1324.

19. Lefcourt HM, Davidson K, Prkachin KM, Mills DE. Humor as a stress moderator in the prediction of blood pressure obtained during five stressful tasks. Journal of Research in Personality 1997; 31: 523-542.

20. Lehman KM, Burke KL, Martin R, Sultan J, Czech DR. A reformulation of the moderating effects of productive humor. Humor: International Journal of Humor Research 2001; 14: 131-161.

21. Kuiper NA, McKenzie S, Belanger KA. Cognitive appraisals and individual differences in sense of humor: Motivational and affective implications. Personality \& Individual Differences 1995; 19: 359-372.

22. Fry PS. Perfectionism, humor, and optimism as moderators of health outcomes and determinants of coping styles of women executives. Genetic, Social, \& General Psychology Monographs 1995; 121: 211-245.

23. Strelau J, Jaworowska A, Wrześniewski K, Szczepaniak P. Kwestionariusz Radzenia Sobie w Sytuacjach Stresowych. CISS. Podręcznik. Polskie Towarzystwo Psychologiczne: Warszawa; 2005.

24. Juczyński Z, Ogińska-Bulik N. Narzędzia Pomiaru Stresu i Radzenia Sobie ze Stresem. Pracownia Testów Psychologicznych Polskiego Towarzystwa Psychologicznego: Warszawa; 2009.

25. Plopa M, Makarowski R. Kwestionariusz Poczucia Stresu - podręcznik. Vizja Press \& IT: Warszawa; 2010.

26. Abel MH. Humor, stress, and coping strategies. Humor: International Journal of Humor Research 2002; 75: 365-381.

27. Rieger A, McGrail PJ. Coping humor and family functioning in parents of children with disabilities. Rehabilitation Psychology 2013; 58: 89-97.

28. Bee H. Psychologia rozwoju człowieka. Zysk i S-ka: Poznań; 2004.

29. Baron RM, Kenny DA. The Moderator-Mediator Variable Distinction in Social Psychological: Research: Conceptual, Strategic, and Statistical Considerations. Journal of Personality and Social Psychology 1986; 51: 1173-1182.

30. Makowska $\mathrm{H}$. Indywidualne strategie radzenia sobie ze stresem: uwarunkowania strategii stosowanych w związku z pracą i ocena ich skuteczności. Promocja Zdrowia, Nauki Społeczne i Medycyna 1996; 8-9: 59-71.

31. Simon JM. The Therapeutic Value of Humor in Aging Adults. Journal of Gerontological Nursing 1988; 14: 8-9.

32. Rim Y. Sense of humour and coping styles. Personality and Individual Differences 1988; 9: 559-564. 